\title{
Contemporary Bangladeshi Poetry in terms of Subject matter, Theme, and Technique: A Reflection
}

\author{
Tusar Talukder
}

Lecturer, Department of English, Central Women's University, Bangladesh

Volume 2, Number 2/2015

DOI prefix: 10.18034/ajhal

Licensed:

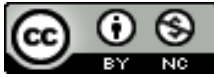

Source of Support: Nil

Conflict of Interest: None Declared

Email for correspondence:

tusar.talıkder@omail.com

\section{ABSTRACT}

Bangladeshi poetry underwent significant changes in cases of subject-matter, theme, and technique over the period of last 40 years. With the passage of time, it embraced as well as adapted to those changes. De facto, after the year of 2000, how poetry has been fashioned in a new way is brought into focus through this research paper. More particularly, I have studied the subject-matter, theme, and language of four contemporary Bangladeshi poets namely Mujtaba Ahmed Murshed, Obayed Akash, Binoy Barman and Rakibul Hasan. I have considered these less known but substantial poets' poetry because while coming across their poems I have minutely noticed the changes and variety they have celebrated through their verses. Therefore, I have selected four poetry collections of the aforementioned poets to expose multifarious aspects of the contemporary Bangladeshi poetry.

Key Words: Nostalgia, symbolism, localness, optimism, pessimism

\section{INTRODUCTION}

Poetry invariably plays a substantial role in shaping the literary landscape of the nation. The history of Bangladeshi literature clearly involves the evolution of Bangladeshi poetry. The transformation particularly occurs due to socio-political changes. And this development process has been continuing for four decades in Bangladesh. During this time, Bangladeshi poetry went though a number of changes in the fields of theme, subject-matter as well as technique. Since it is not possible to discuss many changes happened during the last four decades in one discussion, I have attempted to unveil four facets of Bangladeshi poetry which, I think, will meet the purpose of my essay. In this regard, I have analyzed four contemporary poetry collections of Mujtaba Ahmed Murshed, Obayed Akash, Binoy Barman and Rakibul Hasan to unfold (1) how the contemporary Bangladeshi poetry is powered by nostalgia and reverie, (2) how it is steeped in symbolism, surrealism and magic realism, (3) how it can play a vital role in changing society and (4) how pessimism is deciphered through the contemporary Bangladeshi poetry.

\section{Poetry Powered by Nostalgia and Reverie}

At the outset, I would like to discuss the poetry of Mujtaba Ahmed Murshed to bring out how 'nostalgia and reverie' has become a major theme of the contemporary Bangladeshi poetry. In this regard, I have taken his latest poetry collection entitled Chhayadero Jibon 
Achhey (Shades Have Life Too) into consideration. My study delineates most of the poems from this collection are powered by nostalgia and reverie. Before I start discussing 'nostalgia and reverie' containing in the above-mentioned poetry collection, I have tried to bring into focus some general features of this poetry book. Indeed, 'A poet is a man speaking to men' (11), the most quoted and solemn definition of poetry by William Wordsworth, was the only line I was recollecting while going through the poems. Of course, there lie some relevant reasons for mentioning the axiom. Firstly, there is Murshed's facile diction and, secondly, there is the conversational tone of his poems. As a poet of the 1980s Mujtaba Ahmed Murshed has been ably developing a reader-friendly diction for his poetry that is completely his own. He generally says directly what he intends to say. Therefore, there are few symbols in his poetry. But it is also true in case of a poet that he/she can never compose poetry without symbols. Consequently a poet subconsciously uses some symbols in which the inner themes are expressed in subtle manner. Murshed is also enslaved to his subconscious or unconscious layer of mind. Nonetheless he is not much interested in making his poems intensely symbolic.

Chhayedero Jibon Achhey (Shades Have Life Too) includes forty four poems covering a large variety of subjects being dealt with such as the poet's favorite personalities, happenings of everyday life, memories of the past, dream-like thoughts, love-haunted moments and so on. It becomes crystal clear from this collection that he has a tendency to slip away from following the conventional forms of poetry. Needless to say, such an inclination on Murshed's part delineates he loves to do experiment in the forms of poetry. Amid the poems in this collection, there are some haiku-like poems. In conventional sense, though, these are not haikus. But because of their length and rhythm, they can be looked upon as haiku. It goes without saying that these tiny poems bear very grave meanings which we do not generally find in short-length poems of a shorter length. And almost all the haikus of this collection denote a nostalgic tone. I must assert that any poetry-lover can easily be flabbergasted by reading those short-length poems, which, I believe, have a chance of living long. For example, a haiku-like poem entitled 'Raja' (King) contains the following lines (my translation):

Does anyone know that once there was a lonely king?

Does anyone believe that kings are lonely?

Though you don't regard me as a king,

I always compose songs of loneliness in my mind.

And wander lonely in the wilderness like wild wind. (6)

The collection opens with a poem, 'Chhayar Jibon' (Shade's Life) which delineates how shades, being de-linked from bodies, perform various types of activities, similar to the activities of human beings. Consequently the poet composes (my translation):

Shadows have minds

They also love

Being intensely passionate they go deep down into the water of the oblong lake

They also laugh...shadows have life too. (8)

While translating the lines, no chronological order is followed. I have merely skimmed through the lines to portray a glimpse of the poem. However, the poet comes across as nostalgic in many of the poems in this volume. How Murshed became so nostalgic while weaving a good number of poems is exposed through such compositions such as 'Purono Thikana' (The Previous Address), 'Roddure Station' (The Station Blazing with Sunlight), 'Shesh Bustao Phirbe' (The Last Bus Will Also Come Back), 'Jonmodin' (Birthday) and so 
on. The nostalgia of his poetry can better be realized if someone goes through the following lines grabbed from 'Purono Thikana' (The Previous Address):

The last bus has already left

I am alone in the bus-stop,

Not thinking about to go back.

Were you in that bus?

If I got on the bus

Would I meet you? (6, my translation)

Sometimes, we find Murshed as a stern escapist when we browse the poem 'Shob Sheshe Shopnoi Shotti' (At the End Dream is True) in which he is assailed by doubts and says what he sees today might be unseen tomorrow. For instance (my translation):

Then it seems that only dreams are true

Because they, at last, stay with us and frankly laugh

Then I also fly with my dreams and think

Rest of the things is illusion (6).

Eventually, he keeps his faith in dreams that he thinks are true. Thus, his romantic vision comes to the fore through some of his poems. Murshed has also penned a number of poems in the memory of some of his favorite personalities, namely, Bangabandhu Sheikh Mujibur Rahman, poet Mahbubul Alam Choudhury, and Che Guevara. Furthermore, the collection has a quintessential poem regarding Banalata Sen. Through this poem, the most celebrated character, Banalata Sen, created by Jibanananda Das seeks to come out of darkness because she has passed ages in it sitting face to face. Now she desires to be bathed in sunlight. Mujtaba Murshed dramatically presents this character. Here I have translated a couple of lines to make out his dramatization:

All of a sudden

Banalata calls with her sweet voice..Jibanananda,

I am that girl of yours, Banalata Sen

I desire to be happy singing the song of humanity (8).

The above discussion purports that Mujtaba Ahmed Murshed's poetry is enmeshed in dream-like thoughts that take us to his self-made world. His poetry, without any distortion, encapsulates a moral vision which helps us find an ideal world free of all kinds of anxieties and fears. And undoubtedly, most of the thoughts in his poetry have that soothing power to refresh us. He regales us with his most impressive style of verse making. To sum up Murshed's poetry, the very beginning lines from Adrienne Rich's famous poem 'Our Whole Life' ought to suffice:

Our whole life a translation the permissible fibs (7).

\section{Poetry Steeped in Symbolism, SuRrealism, And Magic-Realism}

In this phase, I will show how the contemporary Bangladeshi poetry is steeped in symbolism, surrealism and magic realism through an analysis of the poetry of Obayed Akash. Moreover, there will be a discussion regarding Akash's use of various techniques in writing poetry. Before I start analyzing the poems, I would like to begin by trying to understand how Obayed Akash has composed his latest book of poetry, Jaa Kichhu Sabuj, Samketmoy (Things that are Green, Symbolic). Were all the poems created consciously or subconsciously or through the blending of the two?

Wordsworth considered poetry as a 'spontaneous overflow of powerful feelings' (11) largely delineating that poetry comes from a subconscious state of mind. But with the 
evolution of time modernists and post-modernists have suggested that the composition of poetry is more associated with the conscious than the subconscious. In other words, while developing the themes and diction of a poem, a poet remains in a very conscious state of mind because the sub-conscious may bar him/her from expressing the anticipated tone of a poem. But I think the most acceptable contemporary theory is that a poem blends both conscious and sub-conscious thoughts. Obayed Akash, a major poet of 1990s' Bangladesh, has emerged with a collection of poetry, Jaa Kichho Sabuj, Samketmoy, comprising 57 poems, published in 2010. In this volume, 42 poems are in free verse while prose-poems are 15 in all. It is very easy to consider Akash as a post-modern poet because his latest collection delineates multifarious post-modern genres, namely, surrealism, symbolism, magic realism and realism. Some may argue that Akash has made his poems intensely symbolic. So, how would we regard him as a post-modern poet? The question has a very simple answer: the use of magic realism and blending of different genres in the poetry and above all his facile and playful diction define him as a post-modern poet. De facto, the prime task of poetry is to create a new world in the mind and Akash's poems have that strength to wander into the realm of the human mind. However, his compositions become outstanding owing to his spontaneity. The words in the poetry become life-like through his competent use. One can instantly draw a picture in his/her mind through a reading of a poem.

In some cases, the words Akash employs in his poetry are unconventional and even regional. This type of passion for localness also bears a vivid sign of Akash's love for postmodernity. Surprisingly enough, he assembles very appropriate words in his poetry without any awkwardness. Critics may argue that Akash has used these appropriate words from a conscious state of mind because it is tough to place the right words in the right places without conscious thinking. My feeling is that the words, sometimes, come to the poet spontaneously when he deeply thinks of any poem. Akash has composed poetry for the very well-educated and thoughtful. To capture the essence of his poetry and philosophy, one ought to read all the poems of Akash altogether. Readers may peruse a collection of essays by the poet, entitled Ghasher Restura (Restaurant of Grass) before they read this recent composition of poetry. Despite being a post-modern poet, Akash extensively uses symbolism. In fact, he creates a web of symbolism with some remarkable dimensions. He engages readers to stop and think with the symbols he uses. He presented some food for thoughts through the symbolic expressions. For instance, the prose-poem entitled 'Abul Hasan Had No Iota of Regret for the Rusty Key of the United Nations' gives the readers a clear image of the contemporary society through the symbolic revelations:

As long as your father survived, I am sure; you did not see this sight that the marginalized people were burying a beautiful dead girl of your Bengal. So, you possessed a deep and proper sense of disparity between police and common people (1).

Obayed Akash feels much more comfortable writing in verse forms rather than in lyrical poetry. It seems his poetry is made of blood and bread. But what does 'blood and bread' indicate? Akash comes up with an immediate answer: poetry produces image and music and blood and bread become an inseparable part of the images. He invariably attempts to bring out things concealed to the surface. Akash realizes through his wanderings in the realm of poetry that poetry itself has a power and beauty to transform life and society.

Some of Akash's other poems need minute observation. A substantial poem entitled 'Upokule Pronoy Kahani' (A Love-affair in Coastal Area) informs us of two lovers by the sea, with milk-like white waves coming towards them furiously to taste their love. What does this scene symbolize? May be, it symbolizes that the pure love is somehow being stigmatized in present times. As well, 'Rajar Mrityu' (King's Death), 'Kotha Bole Mrito 
Dim' (Dead Eggs Speak), 'Tarokader Samsar' (Stars' Family) are packed with magic realities. Amid them, 'Rajar Mrityu' (King's Death) incorporates history, evolution, and human expectations. Through the poem, Akash attempts to surpass time to project upcoming realism. However, to decipher the idea of magic realism, no poem can be proper instance but the poem, 'Patal Train' (Underground Train). In this poem, he explicates the evolution of trains and compares it with our social realities. He humorously informs us that a train compartment may be one type of alternative habitat to live in. The pictograph he develops through this poem is outstanding. To identify some magic realistic happenings I have translated some lines from 'Patal Train':

We have observed through an underground train how a train can be beautified like a house with furniture. And children, aged people, young men, and women, bridegroom and bride, father, mother all together eat nuts and fried chick peas there on the train. But all at once the train turns upside down in an accident, and we notice how people turning into birds and furniture turning into fishes create a new world to live in. I ask those who support this new world to, please come forward and lift their hands to grab the unbelievable prizes. I made this arrangement only for you. The remaining passengers on the train say the process of changing the world is initiated by turning a train compartment upside down (9).

Another poem titled 'Somporko' (Relations) exemplifies a higher state of love. The poem also bears a bit of surreal thought. In one phase of this poem Akash says (my translation):

Centering on the love between you and me,

People say so many things along the way.

The walking fishes crawl in the yard on rainy days,

And you and I know this tale-

Recently our relationship like a pressed down balloon has fallen flat,

Indicating a black and white ancient history

Hearing the roar of clouds,

We have fallen down on the lagoon from the branch of a tree. (1)

Above all, Obayed Akash has picked up his men and women from various classes in our society and decorated his canvas with their activities. The portraits are very lively but sometimes ironically the sprightly dance of the characters alarms us about forthcoming catastrophes and their negative impact on our society.

Archibald MacLeish once said that 'a poem should not mean/But be.'(7) Akash's poems should not only be read to net their inner themes but as an unbounded source of pleasure. For it appears to me that Akash has begun a journey to discover the purity of the soul through his poetic revelations.

\section{Poetry: A Tool for Social Change}

This part of this essay will decipher how poetry can be a better tool to fight the ills of society. In this regard, a collection of poetry, written by Binoy Barman, is considered. The poetry deals with some issues which make us think about why human civilization repeatedly fails to be humane. Binoy Barman, a poet quite different from his other contemporaries, searches for the causes of this failure throughout his latest poetry collection, namely, Binimoye Takey Tumi Katotuku Dao (How much do you give him/her in return?). What makes Binoy different is his belief that he thinks poetry is a quintessential tool which, without an iota of doubt, can bring forth our most expected social changes. He never agrees with those who invariably seek beauty in poetry. While going through the poems of this collection, I have passionately felt the experimentation Binoy had gone 
through in writing the poems. If someone follows the style of Binoy, it will be clear that his conscious state of mind has accelerated him into writing those poems rather than the subconscious. A few months ago, I attended a seminar where the keynote speaker said the conscious state of mind helps him much more than the subconscious state while composing poetry. I think this saying is also applicable to the verses of Binoy Barman.

Having been influenced by the philosophy of Buddha, Binoy Barman wrote a number of poems, captured in the beginning pages of the book. De facto, 'Killing animals is a grave sin', the greatest saying of Buddha, has been the real essence of those compositions. Nevertheless, the view is personal; he wholeheartedly believes that the universe is not only a living place for human beings but rather is a place for all created beings. If a particular species desires to exercise power over other species, the universe will be dysfunctional. He also holds the opinion that human beings have been the most dominant species in terms of knowledge and weapons through the passage of history. Therefore, human beings as a superior species have that strength to destroy other inferior beings. However, human beings must not do that for the sake of maintaining the natural equilibrium of Earth. Binoy firmly believes that to kill animals unnecessarily drags human beings into the state of ferocious animals.

Let me go into a bit of detail about the poetry, leaving behind philosophy for the time being. All the poems, presented with geometrical drawings, purport to some parts of the human body. The symbols used in the drawings wipeout the differences between human beings and animals. Human beings are still animals, as a poem shows human beings are unable to prove their superiority because their behavior is very similar to that of animals. The very last lines support my previous sentence (my translation):

Like animals, human beings are trivial

Destroying the nature, grabs the win

Human beings are human beings due to their clothes

But under the clothes it has a naked identity (10).

Binoy Barman raises a question by composing a poem, 'Love': Where does love reside?

Does it inhabit in our body or mind? The synopsis of the poem delineates that love barely dwells in our mind; it rather sinuously plays in our body. Overall, the chemistry of love always produces a lot of valid questions and at the same time, in most cases, those queries remain unsolved. In general, very few respect poets; a man who composes poetry has become a laughable one in the eyes of many classes of people in our society. A poem 'Someone' portrays this idea. But at the end of the composition, Binoy informs us, borrowing from Jibanananda, that 'some are poets, not all'. Then he also adds a confessional note that he includes himself in those 'all' and is still unable to be in those 'some'. This composition ironically shows us both the power of poetry as well as of the poet.

'Bad Time', a poem written in memory of Humayun Azad, exposes the truth that we have still been unable to exercise full and final freedom of writing, thus indicating that animals like beings (human beings) attacked our eminent writer Humayun Azad but we had no way to save him but cry. As a result, the poet asserts that we need to have full freedom of our pen. Binoy Barman personally believes in optimism. Most of his poems open on a sad note but ends on an optimistic one. To be honest, his entire collection follows this style. The very last poem, 'Last Words', written on being inspired by Rabindranath Tagore, informs us that though we stumble, we still have ways of coming out of the confined tunnel of destruction.

Binoy Barman thinks that poetry can show people the ways of leading an ideal and smooth life. He assumes poetry can influence us positively. Through poetry he asserts that despite having negative aspects in our life we still have ways to overcome those by 
embracing humanity. He never accepts the negativities of life as ingredients of his poems, but portrays the negative sides of life as the causes of our contemporary demeaning state of existence. As a poet, he always likes to maintain the rhyme pattern. If Robert Frost's belief that writing poetry without rhymes is like playing tennis without the net is considered to be true, the poetry of Barman turns out to be truly reader-friendly. In essence, I must say that Binoy Barman believes poetry can play a substantial role in building a world full of love. Barman's thoughts are evocative of P. B. Shelley's philosophy. So a line can relevantly be quoted from Shelley:

If winter comes, can spring be far behind (3)?

\section{Pessimism as a SubJect-Matter of Poetry}

At the end of this essay I have taken a comparatively young poet's poetry into account to provide the idea that contemporary Bangladeshi poetry is not only a tool for delivering optimistic notions which Binoy Barman showed but it has become an essential way of expressing dark and somber mood of human mind. To make the aforesaid statement clearer I need to discuss a latest poetry collection of Rakibul Hasan titled Ekhono Murti Hotey Parini (Yet to Be a Statue), purveying us a clear picture of our contemporary society and modern man's dilemma in present time. Most of the poems of this collection are pessimistic in tone and theme. And his poems remind me those days of my varsity life when I was going through T. S. Eliot's 'The Waste Land'. As soon as I come across the poems of Rakibul, I effortlessly perceive the poet is suffering from a mental agony. Before I forget, I must express my belief that every poet dwells in some agonies and those agonies ultimately compel him/her take pen in hand. Whatever it, what kind of agony Rakibul Hasan suffers from can better be realized if some noteworthy poems from the aforementioned collection are analyzed. The very first poem from the book entitled 'Nobojonmader Proti' (To the New Born) will draw our attention because of the last two lines of the poem indicating the poet's utter despondency with the present world. The same frustration is vivid in other poems such as 'Mangshakirno Nagore' (The Town Full of Fleshy Human Species), 'Probhati' (The Morning Song), 'Bishayoner Madur' (The Mat of Globalization), 'Agachhar Udyan' (The Garden of Weeds), 'Kennorer Jibon' (The life of an Earthworm), 'Somporko' (Relations), 'Barta' (Message), 'Bagh' (Tiger), 'Brishti' (Rain) and so on.

Let me delve deep into some poems. The first poem which enforces me to write something on it is 'The Town Full of Fleshy Human Species' purporting that the whole world has become a place of human flesh. Here flesh is much more important than mind; excessive materialism engulfs peoples' minds. A sensible man has no place in this world; he/she always tries to adapt to the inhumane approaches of other people but fails. The collection having poem namely 'Yet to Be a Statue' is also the title of the book delineating the present world is a place of flatterers. The man who does not have that ability to flatter is quite unfit for this world. The poet here develops a character, which is yet to be an idol because he/she is yet to be a complete flatterer in the world of flattery. How most of the city people are leading their lives is clearly portrayed in the poem entitled 'The life of an Earthworm'. This poem also shows us the pitfalls of class system prevailing in our society. Conversely 'Nijeke Gondar Gondar Lagche' portrays that people, in present time, are so much accustomed to the irrelevancies of the society that people have completely forgotten reacting to the injustices imposed on them. In case of composing the poems, how much pessimistic the poet Rakibul Hasan has been can be felt if I translate two lines from 'The Garden of Weeds': 
There are more weeds than flowers in this garden

So is it needed to clean up all the weeds?

Rather it would be better-

To make a garden of weeds,

Removing all the plants of flowers (5)

Last but not the least, a cogently contrastive composition by the poet Sukanto Bhattacharya can be manifested here:

And leave we will. Yet as long as I breathe,

I will go on clearing the debris

With all my strength

From the face of this earth.

I will make this world habitable for this child;

It is my firm pledge to the newborn (4).

And many years later, Rakibul Hasan dares to say 'abandon all hopes before you enter here'-this appeal to the new born of the world definitely has a reason to the poet. And obviously, why Rakibul does not have any iota of hope and why he does not have the strength like Sukanto are answered through the compositions of this collection.

\section{ConcLusion}

The paper reveals that while Mujtaba Ahmed Murshed is engrossed with dream-like thoughts and nostalgia providing us a moral vision to build an anxiety free society and ideal world, Obayed Akash has been in a journey to discover the purity of soul. And to do so Akash, like French poet Arthur Rimbaud, delivers his thoughts through a plenty of symbolic expressions. Binoy Barman, as well, thinks that poetry can be a better tool to save humanity and civilization from destruction. However, Rakibul Hasan, quite conversely, laments the evaporation of humanity, solidarity, and ethnicity from us. In short, I have tried to capture the dimension Bangladeshi poetry celebrates in recent times.

\section{REFERENCE}

AKASH, O. (2011) Jaa Kichoo Sabuj, Samketmoy (Things that are Green, Symbolic). 2nd Ed. Dhaka: Ittadi Publications.

BARMAN, B. (2012) Binimoye Tumi Take Kototuko Dao (How Much Do You Give Him/Her in Return). 2nd Ed. Dhaka: Pathsutra.

HUTCHINSON, T. and MATTHEWS, G. M. ed. (1970) The Complete Poetical Works of Percy Bysshe Shelley. 2nd ed. Oxford: Oxford UP.

HUDA, N. (2013) Recent trends in the contemporary poetry of Bangladesh. The Independent. [Online] 5th January. p.15. Available from: http://www.theindependentbd.com. [Accessed: 20th July 2014]

HASAN, R. (2010) Ekhono Murti Hotey Parini (Yet To Be an Idol). 1st Ed. Dhaka: Gas Phul Nodi.

MURSHED, M. A. (2011) Chhayadero Jibon Achhey (Shades Have Life Too). 1st Ed. Dhaka: Dhrubapada Prokashon.

MACLIESH, A. (1976) Ars Poetica. Oxford: Oxford UP.

TALUKDER, T. (2012) Poetry powered by nostalgia and reverie. The Daily Star. [0nline] 2nd June. Available from: http://archive.thedailystar.net/newDesign/news-details.php?nid=236650. [Accessed: 22nd August 2012].

TALUKDER, T. (2011) Poetry steeped in symbolism. The Daily Star. [Online] 3rd September. Available from: http://archive.thedailystar.net/newDesign/news-details.php?nid=200852. [Accessed: 19th October 2012]. 
TALUKDER, T. (2013) Poetry: a tool for social change. The Daily Star. [Online] 5th January. Available from: http://archive.thedailystar.net/newDesign/news details.php?nid=263836. [Accessed: 20th August 2014].

WORDSWORTH, W. (1995) Preface to the Second Edition of the Lyrical Ballads. English Romantic Writers. 2nd Ed. Oxford: Oxford UP.

This article is is licensed under a Creative Commons Attribution-NonCommercial 4.0 International License. Attribution-NonCommercial (CC BY-NC) license lets others remix, tweak, and build upon work non-commercially, and although the new works must also acknowledge \& be non-commercial.

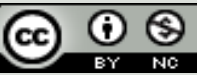

How to Cite: Talukder T. 2014. Contemporary Bangladeshi Poetry in terms of Subject matter, Theme, and Technique: A Reflection Asian Journal of Humanity, Art and Literature, 2, 61-70. 


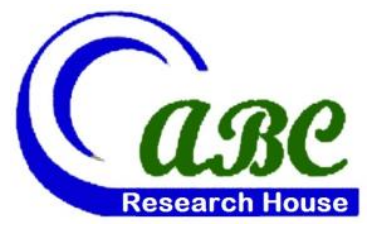

- Off Pantai Dalam, Kuala Lampur, Malaysia

- Road \# 4, Shyamoli, Dhaka-1207, Bangladesh

- 3900 Woodhue Place, Alexandria, VA 22309, USA

www.abcreorg.weebly.com / www.abcjournals.net

Asian Business Consortium (ABC) is a multi-disciplinary research, training, publishing, digital library supporting and service house. Though founded in 2010 as the Business and Computing organization of Asia, it was reconstituted as the ABC in 2011. It has been working for creating and nurturing talents in USA, Malaysia and Bangladesh since its inception. The objectives of consortium are solely centered round the welfare and humane attitude of the founders who enthusiastically took up this noble cause and materialized it with a view to promote research and educational activities for the encouragement of scholars to develop their knowledge, to publish their analysis oriented scientific researches in international Journals, books, the task of organizing workshops, seminars, conferences, training, personality development programs and allied services.

In addition to research activities, $\mathrm{ABC}$ provides a good number of scholarships to the poor and meritorious students at various levels of education throughout the world. It plays an important role in the field of research by funding research projects and publishing the research papers. This consortium will unquestionably become the mouth-piece of the dark horses and unacknowledged scholar whose endowed and commendable contributions shall be provided an outlet keeping in mind the greater good of the larger society of the world.

$A B C$ runs the following international referred journals for creating a platform to share the thoughts of professionals, scholars and academicians throughout the world.

\section{ABC Publications (ABC Journals)}

- Asian Accounting and Auditing Advancement (4A Journal)

- Asian Business Review (ABR)

- Asian Journal of Applied Sciences and Engineering (AJASE)

- Global Disclosure of Economics and Business (GDEB)

- $\quad$ ABC Journal of Advanced Research (ABC-JAR)

- International Journal of Reciprocal Symmetry and Theoretical Physics (IJRSTP)

- American Journal of Trade and Policy (AJTP)

- Asian Journal of Humanity, Art and Literature (AJHAL)

- Malaysian Journal of Medical and Biological Research (MJMBR)

- Asia Pacific Journal of Energy and Environment (APJEE)

- $\quad$ Engineering International (EI)

- $\quad$ ABC Research Alert (Online)

Each journal home page provides specific information for potential authors and subscribers. Open access policy, the quick review process, rich editorial boards and quality publications have already made ABC Journals unique. ABC Journals are published under the direct supervisions of renowned academicians of the world.

Collaboration in Conference: $\mathrm{ABC}$ considers high-quality conference papers for publication. Please contact us for detailed information.

Collaboration in Publishing: If you like to start writing a book, propose a new journal or advertise in $\mathrm{ABC}$ journals, please feel free to contact us. 